\title{
SPC 委員会活動報告
}

\section{動物モデル部会}

1宮崎大学医学部病理学, 2第一三共株式会社生物医学研究所,

3浜松医科大学薬理学, ${ }^{4}$ 長浜バイオ大学アニマルバイオサイエンス学科

山下 篤 $^{1}$, 森島義行 ${ }^{2}$, 梅村和夫 ${ }^{3}$, 永井信夫 ${ }^{4}$

\section{第 XI 因子阻害薬}

ワルファリンによる静脈血栓塞栓症予防は, PTINRを指標として確立されてきたが, 出血性副作用, 薬剂・食物との相互作用, 個人差からくるモニ夕 リングの必要性, 狭い治療域などの制限があった。 トロンビンや活性化第 X因子を標的とした経口抗 凝固薬が上記欠点を補う目的で開発され，血栓塞栓 症の予防薬として使用されている1)。しかしながら， 1 年間に抢よそ3\%の出血性合併症やモニタリング が難しいという課題がある1).

血栓塞栓症は大きく成長した血栓(発症に至る静 脈血栓は動脈血栓と比べてはるかに大きい)が剥離 し末梢の血管を閉塞することで発症する。血液凝固 は血管壁や結合組織・活性化した単球や癌細胞に存 在する組織因子から始まり, 生じたトロンビンは第 XI 因子 (FXI) を活性化することで, FIX, FX, 更な るトロンビン産生へと繋がる血液凝固の増幅系を形 成すると考えられている(図)。この増幅経路は血小 板上で効率的に進行し, 補助因子である FVIII や $\mathrm{FV}$ も同様に血小板上で効率的に活性化される。こ のように FXI は血栓の成長段階に寄与するとされ 次世代抗凝固薬の標的因子の一つであり, アンチ センスオリゴヌクレオチドによる第 2 相臨床試験が 報告されるに至っている2)。本稿では, FXI 阻害薬 の開発における動物モデルでの抗血栓効果や出血の 評価を静脈血栓に焦点を絞り概説する。なお，本文 では凝固因子をローマ数字(FXI 等)で記載する。

\section{血栓症予防薬としての臨床的背景：FXI 欠乏症 の出血傾向と血栓症}

ヒトの FXI 欠乏症では, FVIII 欠乏症 (血友病A), FIX 欠乏症 (血友病 B) と比べて出血傾向の程度は軽 い. 自然出血はまれで，ほとんどが外傷や手術によ るもの，とくに線溶活性の高い臟器である尿路系や 口腔で生じる ${ }^{3)}$ ，それにはFXIによって間接的に増 加する thrombin-activatable fibrinolysis inhibitor の関与 が示唆されている. FVIII やFIX 欠乏症との出血傾 向の違いはFXI が久乏しても FVIIによるFIX の活 性化やトロンビンによる FVIII の活性化により止血 がなされることによるものと考えられる(図)，血栓 性合併症に関する情報はイスラエルの久乏症家系か らの報告に限られているが, FXI 欠乏症では脳血栓 塞栓症 ${ }^{4)}$ や深部静脈血栓症 ${ }^{5)}$ の発症頻度が少ない. 一方, FXI の増加が深部静脈血栓症や脳梗塞の発症 と関連している ${ }^{6-8)}$. これらの臨床的特徵や増幅系因 子としての機能から, FXI 阻害物質/薬が出血合併 症の少ない抗血栓薬の候補として注目されている。

\section{FXI ノックアウトマウスの表現型}

FXI ノックアウトマウスはヒト同様自然出血を認 めず，出血時間は延長しない，塩化鉄を用いた血栓 モデルでは, 下大静脈, 頸動脈において血栓抵抗性 を示した ${ }^{9,10)}$. 経時的に血栓形成を観察した検討で は，血栓形成の早期に影響せず，形成された血栓の 安定性が低下していた ${ }^{11)}$ 。これらの実験結果はヒト の FXI 欠乏症に合致する。 


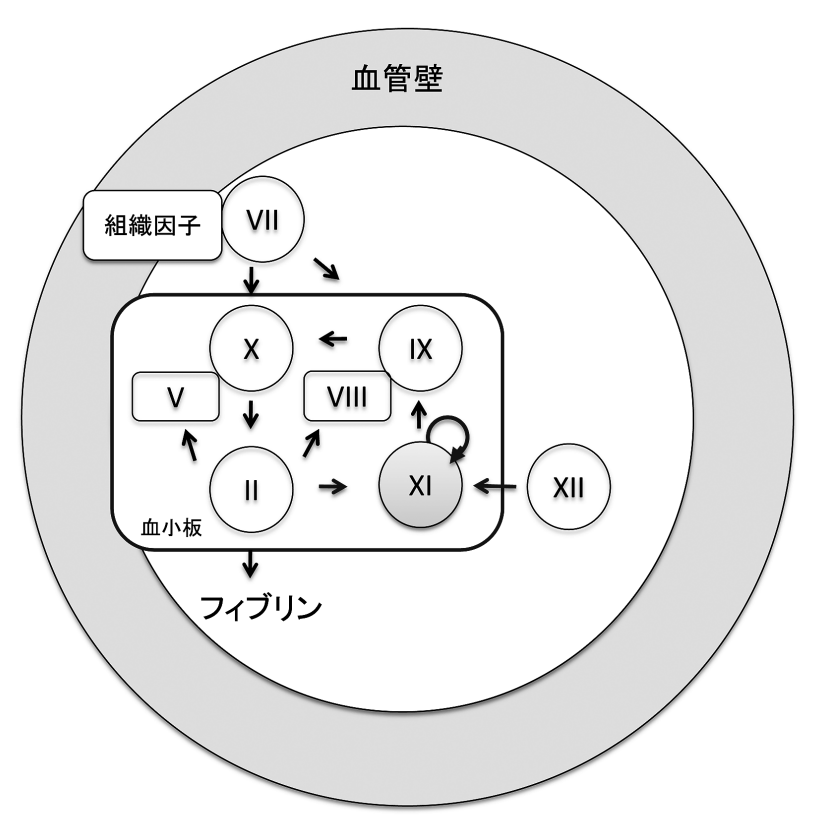

図血液凝固のカスケード

血液凝固反応は主に血管壁や流入した組織由来の組織因 子と血液中の FVII の結合により開始され，FVIII や FXI を介した経路により増幅される。は酵素, 口は補助因 子，枠は血小板を示す，FXIはトロンビン(II)，FXI その もの，FXII から活性化される，簡易にするため F (因子) 表示, 前駆体からの活性化, FXIII, 阻害因子等を記載し ていない.

\section{動物モデルにおける FXI 阻害薬の効果と出血評価}

ヒトの FXI 欠乏症やノックアウトマウスの表現型 より, 出血性リスクの低い抗凝固薬として FXIアン チセンスオリゴヌクレオチド，抗 FXI 抗体，低分子 FXI 阻害薬などが開発され動物モデルによりその効 果や出血傾向が評価されている(表).

\section{(1) FXI アンチセンスオリゴヌクレオチド}

アンチセンスオリゴヌクレオチドは肝臓において FXI 特異的に合成阻害効果を示す。週 2-3 回, 数週 間の皮下投与により血漿の FXI 活性をおよそ7090\%減少させた。これまでにマウス静脈血栓モデル での抗血栓効果 ${ }^{12}$, , ウサギ静脈カテーテルの血栓性 閉塞の延長 ${ }^{13)}$, ヒヒシャントモデルでの血小板集積 の抑制 ${ }^{14)}$ など抗血栓作用が報告されている。出血評 価では, マウス(尾出血, 部分肝切除 $)^{12}$, ヒヒ(皮膚 切開 $)^{14)}$ ，カニクイザル(尾，皮膚，歯肉傷害 $)^{15}$ にお いて対照との差を認めなかった。また，血漿由来
FXI の中和効果が確認された。

\section{(2) 抗 FXI 抗体}

XI-5108 は軽鎖を認識し立体障害によりヒト，ウ サギ FXI の酵素活性を阻害する ${ }^{16)}$. aXIMab は重鎖 第3Apple ドメイン；A3 に結合しヒト，ヒヒ FXIの 酵素活性を阻害する ${ }^{17)}$. 14E11 はA2 ドメインに結 合しヒト，ヒヒ，ブタ，ウサギ，マウス FXI の FXII による活性化を阻害する(トロンビンと活性化 FXI による活性化は阻害しない) ${ }^{18)}$ ＸX-5108や aXIMab は静脈内への単回投与によりそれぞれ活性化部分卜 ロンボプラスチン時間 (aPTT)の著明な延長や血漿 の FXI 活性を 90\%以上減少させた。XI-5108 はウサ ギ静脈血栓モデルでの抗血栓作用 ${ }^{19)} に$ 加えて, 血栓 作成後の投与で血栓成長を抑制した ${ }^{20)}$. aXIMabは ヒヒシャントモデルでグラフト内の血小板やフィブ リン集積を抑制した ${ }^{17)}$. 一方 14E11 は同様のヒヒ シャントモデルでグラフト内のフィブリン集積のみ を抑制した ${ }^{18)}$ ．これは抗体間の作用機序の違いによ るものと推察される。出血評価では XI-5108 はウサ ギ爪出血時間 ${ }^{16)}$, aXIMab はヒヒ皮膚出血時間 ${ }^{17)}$ に おいて対照との差を認めなかった。

\section{(3)低分子 FXI 阻害薬}

FXI はキモトリプシンセリンプロテアーゼに属す るため活性中心阻害薬の特異性が課題となるが数種 類の低分子阻害薬が開発されている。ペプチド模倣 薬は活性化 FX, トロンビン, 活性化プロテイン C に対してそれぞれ 260，340，3000 倍以上の選択性 を持つが，カリクレインやトリプシンへの選択性は 低い。その静脈内投与により，ラット静脈血栓モデ ルで抗血栓作用を示した。一方, より高用量におい ても腸間膜動脈の出血時間延長を認めなかった ${ }^{21)}$.

BMS-262084 は活性中心のセリン残基と共有結合 する不可逆性の低分子阻害薬で他の凝固線溶系酵素 に対して少なくとも 170 倍の選択性を持つが, トリ プターゼやトリプシンに対する選択性は低い. BMS262084 は静脈内持続投与により aPTT を延長させ, ラット, ウサギ静脈血栓モデルで抗血栓作用を示し た。ラット(爪出血，腸間膜血管穿刺，腎皮質切開) の出血時間は対照と同等だったものの, 高用量の投 与によりウサギ爪出血時間を 1.5 倍延長させた ${ }^{22,23)}$.

このように動物モデルでの結果はおおむね一致 し，出血時間を延長せずに血栓抑制作用を示してお 


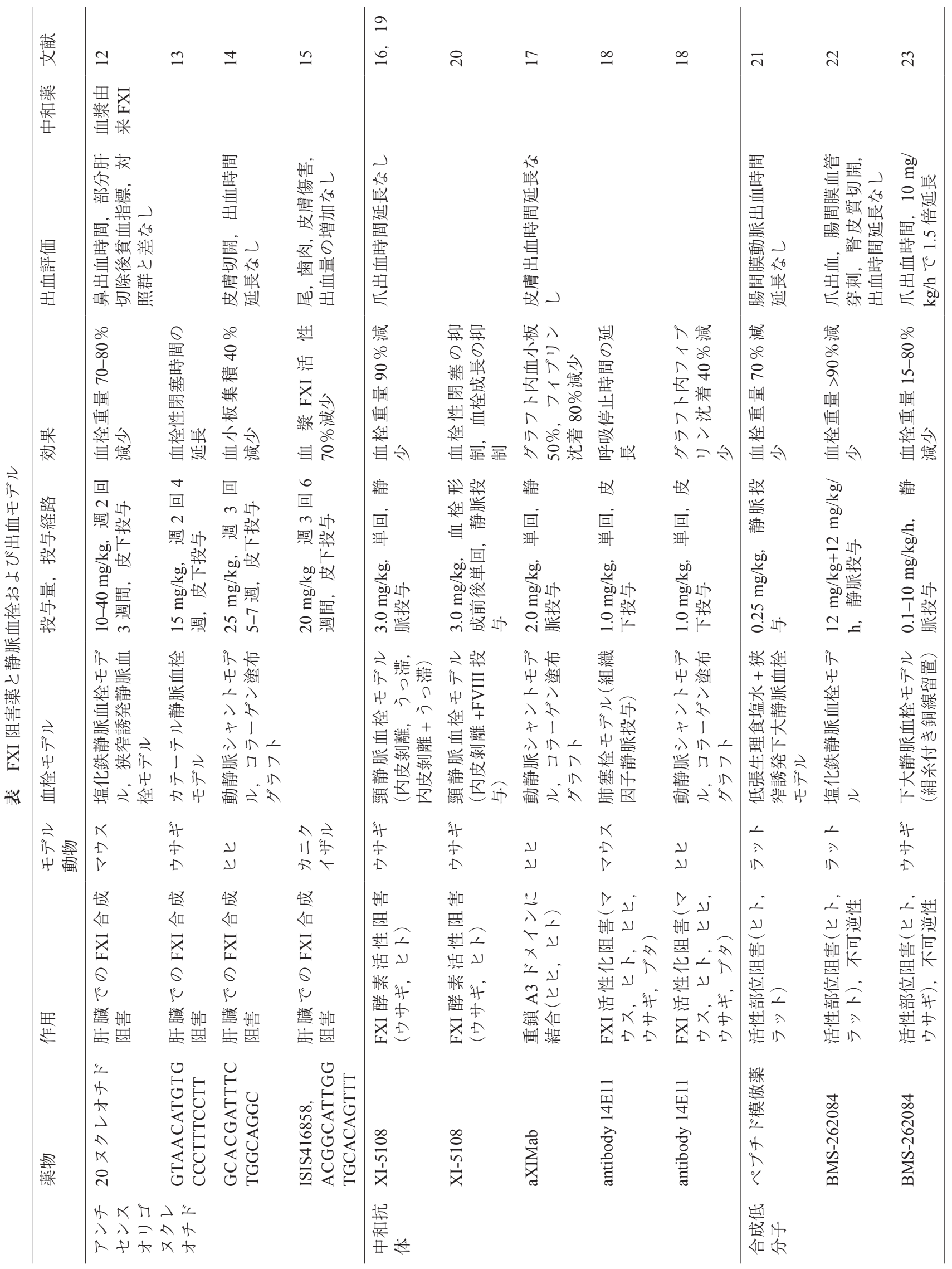


り，FXI 阻害により出血傾向を呈さずに抗血栓作用 が得られる可能性を示唆している。製剂ごとの違い をまとめると，アンチセンスオリゴは特異性が高く FXI の投与で中和(補充) 可能であるが，頻回の皮下 投与が必要である。抗体は特異性が高く作用時間が 長いが，非経口投与で中和薬に課題がある。低分子 阻害薬は経口薬としての可能性があるが，特異性や 中和薬に課題がある。

\section{FXI 阻害薬の臨床試験}

FXI アンチセンスオリゴヌクレオチドは第 1 相試 験で抗 FXI 活性や安全性が確認され，膝関節手術 後の深部静脈血栓症予防における第 2 相試験(比較 的少数の症例を対象とし, 薬剤の安全性および有効 性，用法，用量を調べるための試験)が行われた ${ }^{21}$. 被験者は，術前およそ 5 週間で 7 回，術後 4 日で 2 回の皮下投与を受け，術後の静脈血栓症に対し低分 子量ヘパリンと同等以上の予防効果が確認された。 一方注目される出血事象はアンチセンスオリゴ群の 3\%，低分子へパリン群の 7\%に認め減少傾向を認 めるものの有意差はなかった.

\section{まとめ}

出血性副作用が少ないと予想される FXI 阻害薬は 次世代の抗凝固薬として期待される。一方, 組織因 子が持続的に供給されるような病態(癌細胞の静脈 浸潤，外科的組織障害など)に伴う静脈血栓症は相 対的に FXI の関与が少ないことが想定されるため, 動物モデルなどによるさらなる検討が必要と考えら れる。また，上記臨床試験 ${ }^{2}$ での出血頻度 (3\%) は 少ないとは言えずさらなる安全性向上，モニタリン グ方法や中和薬の開発に期待したい.

著者の利益相反 $(\mathrm{COI})$ の開示 :

森島義行：役員・顧問職・社員など(第一三共株式 会社 社員）

その他著者全員の利益相反 $(\mathrm{COI})$ の開示 :

本論文発表内容に関連して開示すべき企業との利益 相反なし

\section{文献}

1) McMahon BJ, Kwaan HC: The new or non-vitamin K antagonist oral anticoagulants: what have we learned since their debut. Semin Thromb Hemost 41: 188-194, 2015.

2) Büller HR, Bethune $C$, Bhanot $S$, Gailani D, Monia BP, Raskob GE, Segers A, Verhamme P, Weitz JI; FXI-ASO TKA Investigators: Factor XI antisense oligonucleotide for prevention of venous thrombosis. N Engl J Med 372: 232-240, 2015.

3) Duga S, Salomon O: Congenital factor XI deficiency: an update. Semin Thromb Hemost 39: 621-631, 2013.

4) Salomon O, Steinberg DM, Koren-Morag N, Tanne D, Seliqsohn U: Reduced incidence of ischemic stroke in patients with severe factor XI deficiency. Blood 111: 4113-4117, 2008.

5) Salomon O, Steinberg DM, Zucker M, Varon D, Zivelin A, Seligsohn U: Patients with severe factor XI deficiency have a reduced incidence of deep-vein thrombosis. Thromb Haemost 105: 269-273, 2011.

6) Cushman M, O'Meara ES, Folsom AR, Heckbert SR: Coagulation factors IX through XIII and the risk of future venous thrombosis: the Longitudinal Investigation of Thromboembolism Etiology. Blood 114: 2878-2883, 2009.

7) Meijers JC, Tekelenburg WL, Bouma BN, Bertina RM, Rosendaal FR: High levels of coagulation factor XI as a risk factor for venous thrombosis. N Engl J Med 342: 696-701, 2000.

8) Yang DT, Flanders MM, Kim H, Rodgers GM: Elevated factor XI activity levels are associated with an increased odds ratio for cerebrovascular events. Am J Clin Pathol 126: 411415, 2006.

9) Rosen ED, Gailani D, Castellino FJ: FXI is essential for thrombus formation following $\mathrm{FeCl} 3$-induced injury of the carotid artery in the mouse. Thromb Haemost 87: 774-776, 2002.

10) Wang X, Smith PL, Hsu MY, Gailani D, Schumacher WA, Ogletree ML, Seiffert DA: Effects of factor XI deficiency on ferric chloride-induced vena cava thrombosis in mice. J Thromb Haemost 4: 1982-1988, 2006.

11) Renné T, Pozgajová M, Grüner S, Schuh K, Pauer HU, Burfeind P, Gailani D, Nieswandt B: Defective thrombus formation in mice lacking coagulation factor XII. J Exp Med 202: 271-281, 2005.

12) Zhang H, Löwenberg EC, Crosby JR, MacLeod AR, Zhao C, Gao D, Black C, Revenko AS, Meijers JC, Stroes ES, Levi M, Monia BP: Inhibition of the intrinsic coagulation pathway factor XI by antisense oligonucleotides: a novel antithrombotic strategy with lowered bleeding risk. Blood 116: 4684 4692, 2010.

13) Yau JW, Liao P, Fredenburgh JC, Stafford AR, Revenko AS, Monia BP, Weitz JI: Selective depletion of factor XI or factor XII with antisense oligonucleotides attenuates catheter thrombosis in rabbits. Blood 123: 2102-2107, 2014.

14) Crosby JR, Marzec U, Revenko AS, Zhao C, Gao D, Matafonov A, Gailani D, MacLeod AR, Tucker EI, Gruber A, Hanson SR, Monia BP: Antithrombotic effect of antisense factor XI oligonucleotide treatment in primates. Arterioscler Thromb Vasc Biol 33: 1670-1678, 2013.

15) Younis HS, Crosby J, Huh JI, Lee HS, Rime S, Monia B, 
Henry SP: Antisense inhibition of coagulation factor XI prolongs APTT without increased bleeding risk in cynomolgus monkeys. Blood 119: 2401-2408, 2012.

16) Yamashita A, Nishihira K, Kitazawa T, Yoshihashi K, Soeda $T$, Esaki K, Imamura T, Hattori K, Asada Y: Factor XI contributes to thrombus propagation on injured neointima of the rabbit iliac artery. J Thromb Haemost 4: 1496-1501, 2006.

17) Tucker EI, Marzec UM, White TC, Hurst S, Rugonyi S, McCarty OJ, Gailani D, Gruber A, Hanson SR: Prevention of vascular graft occlusion and thrombus-associated thrombin generation by inhibition of factor XI. Blood 113: 936-944, 2009.

18) Cheng Q, Tucker EI, Pine MS, Sisler I, Matafonov A, Sun MF, White-Adams TC, Smith SA, Hanson SR, McCarty OJ, Renné T, Gruber A, Gailani D: A role for factor XIIa-mediated factor XI activation in thrombus formation in vivo. Blood 116: 3981-3989, 2010.

19) Takahashi M, Yamashita A, Moriguchi-Goto S, Sugita C, Matsumoto T, Matsuda S, Sato Y, Kitazawa T, Hattori K, Shima M, Asada Y: Inhibition of factor XI reduces thrombus formation in rabbit jugular vein under endothelial denudation and/or blood stasis. Thromb Res 125: 464-470, 2010.
20) Sugita C, Yamashita A, Matsuura Y, Iwakiri T, Okuyama N, Matsuda S, Matsumoto T, Inoue O, Harada A, Kitazawa T, Hattori K, Shima M, Asada Y: Elevated plasma factor VIII enhances venous thrombus formation in rabbits: contribution of factor XI, von Willebrand factor and tissue factor. Thromb Haemost 110: 62-75, 2013.

21) Lin J, Deng H, Jin L, Pandey P, Quinn J, Cantin S, Rynkiewicz MJ, Gorga JC, Bibbins F, Celatka CA, Nagafuji P, Bannister TD, Meyers HV, Babine RE, Hayward NJ, Weaver D, Benjamin H, Stassen F, Abdel-Meguid SS, Strickler JE: Design, synthesis, and biological evaluation of peptidomimetic inhibitors of factor Xia as novel anticoagulants. J Med Chem 49: 7781-7791, 2006.

22) Schumacher WA, Seiler SE, Steinbacher TE, Stewart AB, Bostwick JS, Hartl KS, Liu EC, Ogletree ML: Antithrombotic and hemostatic effects of a small molecule factor XIa inhibitor in rats. Eur J Pharmacol 570: 167-174, 2007.

23) Wong PC, Crain EJ, Watson CA, Schumacher WA: A smallmolecule factor XIa inhibitor produces antithrombotic efficacy with minimal bleeding time prolongation in rabbits. J Thromb Thrombolysis 32: 129-137, 2011. 